\title{
Improvement of Human Resources Performance Through Online Presence Applications Based on Android Using UML - Iconix process
}

\author{
Amirul Mustofa ${ }^{1}$, Achmad Muzakki ${ }^{2}$, Slamet Kacung ${ }^{3}$,Eny Haryati ${ }^{4}$ \\ \{amirul.mustofa@unitomo.ac.id ${ }^{1}$, achmad Muzakki@unitomo.ac.id ${ }^{2}$, slamet@unitomo.ac.id $\left.{ }^{3}\right\}$ \\ ${ }^{1,4}$ Lecturer in the public Administration Study Program-Faculty of Administrative Sciences, Dr. \\ Soetomo University, Indonesia \\ ${ }^{2,3}$ Lecturer in the informatics Engineering Study Program-Faculty of Engineering, Dr. Soetomo \\ University, Indonesia
}

\begin{abstract}
This study aims to build and design an online presence system based on Android using the Unified Modeling Language (UML) Iconix Process. This modeling is designed using: domain models, use case diagrams, robustness diagrams, sequence diagrams, and graphical user interface (GUI) storyboards. To implement this modeling, software requirements specification (SRS) is needed, so that the modeling design is in accordance with user needs. this is the modeling of the performance of human resources in universities using UML software - Iconix Process, which produces software requirements specifications. With this SRS, it can reduce the time and cost of building an online android presence application.
\end{abstract}

Keywords: Human resources, online presence application, UML.

\section{Background}

The implementation of the present application through fingerprint technology in universities still leaves some obstacles, including the limited number of fingerprint tools that do not compare with the number of human resources (lecturers, employees, and students); there is no transparency in attendance, because lecturers, employees, and students cannot monitor attendance at all times; and authorized leaders cannot monitor and evaluate the presence of resources quickly and in real-time. The application of attendance at universities that use finger print with computerized assistance, also still encounters several issues, including not being able to answer accuracy, the presence and recapitulation of data every month, so that to attend attendance is still often wrong, late, and less effective. While the presence of students used for the teaching and learning process is used to supervise the activity of lecturers and students not yet integrated with the academic system. In other words, the lecturer and student attendance recap, lecture minutes, lecture schedule, lecture material are still carried out using a separate system.

Some previous studies such as K. R. Pireva, et al (2013), Produce that presence applications use Radio Frequency Identification (RFID) which is used to track student attendance automatically[1]. To work on this application requires an RFID Card, so it requires a very expensive cost. J. Chi et al. Research (2016) that online presence has an impact on the learning performance of a student in college [2]. Syahputri research(2017), resulted that the implementation of an online E-logbook presence system on employee work discipline partially had a positive impact[3]. 
Poor human resource work discipline, according to some experts in human resource management, has an impact on the poor performance of human resources. When the performance of human resources is not good or still low, it will affect the strategic objectives of the management of an institution. Therefore, strategies need to be developed to prepare an increase in strategic plans through the preparation of ICT applications (Mamoudou and Joshi, 2014)[4]. Preparation of ICT applications in this global era is needed to support the improvement of human resource performance in a moderate manner, including in supporting the strategic plan of an institution that has been established on key performance indicators of human resources. Various weaknesses in the use of fingerprint technology in an effort to improve the performance of human resources are considered by the researchers to build and design android-based online presence applications using UML - Iconix Process. This application is expected to be a state of the art that is able to answer various problems against the weaknesses of the present model used by universities in an effort to improve the performance of human resources.

\section{Review theory}

\subsection{Unified Modeling LanguageIconix Process}

Unified modeling language Concrete Process (UML - Iconix Process) is a standard for documenting, specifying, and building software systems. Which is a set of structures and techniques for object-oriented program design (OOP) modeling and its applications? Methods for developing an object-oriented program (OOP) system and a group of tools to support system development. UML - Iconix Process is one of the software engineering models used for software development. The approach of UML - Iconix Process is among the very broad Rational Unified Process (RUP) and extreme programming (XP). UML - Iconix Process uses use cases, such as Rational Unified Process, without using many tables. In addition, UML Iconix Process is also relatively simple compared to other UML, including the use of very few diagrams (Qingxiong Ma, 2019))[5], but do not ignore analysis and design.

\subsection{Design of Business Process Model and Notation}

Business Process Model and Notation (BPMN) in Indonesia has been regulated by the government through Menpan regulations and Bureaucratic Reform Number 12 of 2011[6]. The material substance of the regulation is that Business Process Modeling Notation must be used as a reference for ministries or regional governments to develop Standard Operating Procedures. The main objective of BPMN is to describe a notation to all users in order to understand the business processes contained in the Android-based online presence design system. 


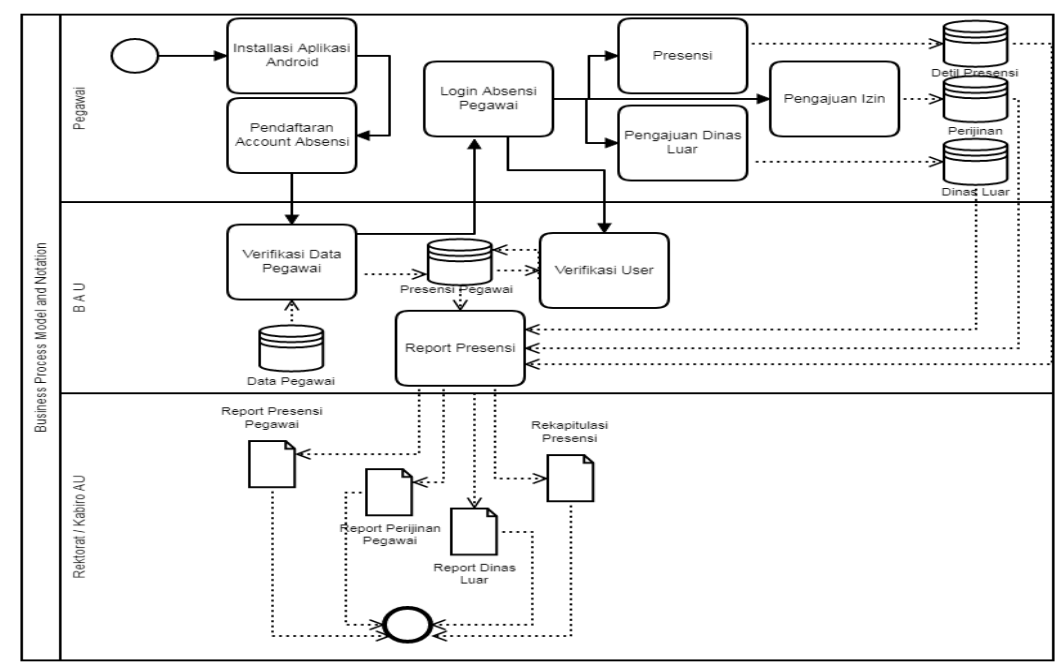

Fig. 1. Employee Performance Factors

\subsection{Human Resources Performance Through Online Presence}

The performance of human resources or employees is the work of human resources as a whole or during a certain period both in quality and quantity based on criteria that have been determined and agreed upon in advance. According to Siagian quoted by Ririn and Hadi (2016)[7]states that employee performance is influenced by several factors, namely compensation, employee training, work environment, work culture, leadership, motivation, discipline, job satisfaction. This study, researchers only focus their research on work discipline as a factor that determines the performance of human resources. In this regard, researchers are trying to improve the performance of human resources through the preparation of ICT applications with UML modeling - Iconix process.

Some research results indicate that online presence applications in the sense of ICT use have a positive impact not only on individual performance but have a positive impact on overall organizational performance (Elhazam, 2015)[8]. However, ICT-based application models must be designed integrated into an institution. Daniel Karanja et.al (2017)[9]formulated the results of his research that ICT made in an integrated manner had a positive effect on the performance of human resources at state universities in Kenya. However, they emphasized that ICT needs to be supported by the performance and function of administrative staff and supported by the strategic plan of the university in the implementation of recruitment and selection and development of employees, as well as employee payroll planning.

In an effort to improve employee performance that higher education institutions, can not be separated from the global development of ICT through integrated ICT applications. This is so, that integrated ICT will be able to solve various problems and the best solutions to lead to competitive advantage from higher education institutions. In connection with that, higher education institutions, it is not possible to switch to other systems or models outside of integrated ICT, they will even find difficulties in maintaining and increasing the number of prospective students, the performance of employees and lecturers(Danil Karanja 2016)[10]. It is important to note that integrated ICT to manage human resources can be realized using the 
prerequisites: infrastructure; good software; analysis of prospective users; identification of functional procedures specified; and involvement and support from top management(Danil Karanja 2016)[10]. with such prerequisites, integrated ICT will be an appropriate strategy to improve the efficiency and effectiveness of the performance of individual institutions, groups, and institutions of higher education.

\section{Method}

The method used to show the process of analyzing \& designing online applications based on android using UML - Iconix process:

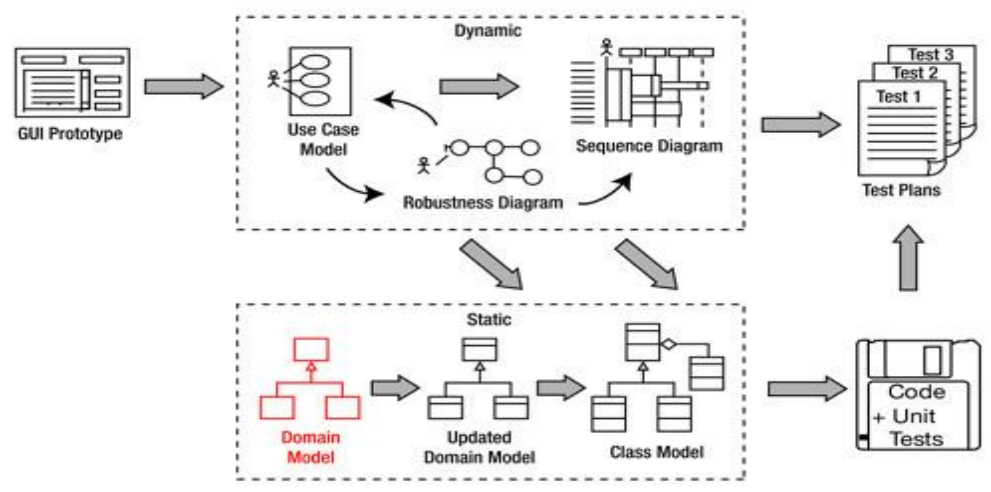

Fig. 2. UML-Iconix Process [11]

UML - Iconix process design method in this research is carried out through three stages, namely: use a cased diagram, robustness diagram, and sequence diagram.

a. The use case diagram stage, divided into four stages, namely: the functional requirements stage, trying to collect all the functional requirements needed in making software. The use case is a functional requirement of software development; the domain modeling stage, the foundation of the static part of the unified modeling language. Modeling domains are obtained from extracting nouns obtained from functional requirements. Words of objects obtained are interconnected according to needs and software; stage of behavioral requirements or use case modeling. Use case modeling is part of the Iconix process that explains everything that the user does from the system. This process explains everything that the user does and the relationship to the response from the system[12]. In this process, software design is expected to be explained in detail because the software is dedicated based on user needs; and milestone stage 1: Requirements Review. At the milestone stage 1, the review requirements are reviewed as follows: (i) Ensure that the use case test is in accordance with the user's needs; (ii) Ensure that the domain diagram has the right relationship, and (iii) Ensure that the use case is organized in one package.

b. Robustness diagram stage. At this stage it is divided into three stages, namely: the robustness analysis stage is an analysis carried out by making a robustness diagram that connects analysis and design; the update domain model stage is a change in the domain model that has been made according to the results of robustness analysis. Changing is done by adding an absent class, eliminating ambiguity, and adding attributes to the 
domain object; and milestone stage 2: Preliminary Design Review (PDR), is the stage for analyzing the suitability of use case text with robustness diagrams, and ensuring that all entities contained in the robustness diagram have been updated in the domain model.

c. Sequence diagram stage. Sequence diagrams are diagram flow arranged based on robustness diagrams. This diagram is created for each use case. The purpose of this diagram is to allocate behavior to the class. The stages of sequence diagrams are divided into two stages, namely: update domain model is the stage of change in the domain model based on the results of sequence diagrams. In this change there are additional operations on the domain object; the second stage produces milestone 3: Critical Design Review (CDR). At this stage a review is carried out, to ensure that the design has fulfilled all the needs from the results of previous identification.

\section{Result}

The results of this study produce software requirements specifications, which consists of graphical user interface (GUI), use case diagrams, robustness diagrams, and sequence diagrams.

\subsection{GUI}

\subsubsection{GUI Download Online Application}

In this design, users must have a file "Online Presence Application of Dr. Soetomo University". Which will be uploaded to the play store so that all employees can download independently. As in the Graphical User Interface (GUI) view.

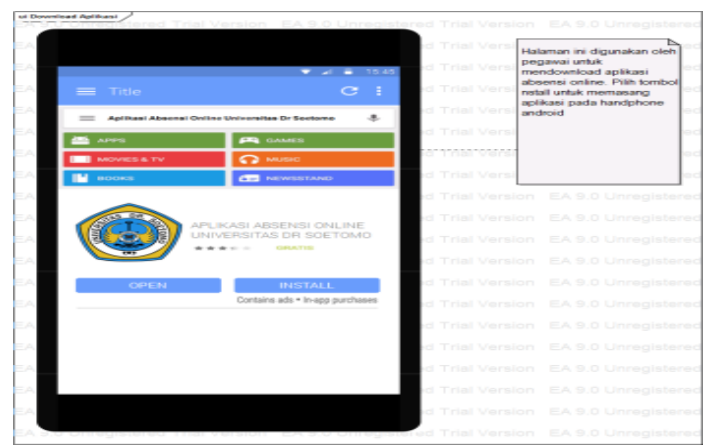

Fig. 3. GUI Download the Online Presence Application

\subsubsection{GUI for Licensing and Services Outside Online Presence}

Employees can do licensing or not enter work through an online presence application. Employees can do a permit by filling out the licensing form and uploading data / licensing letters on the online presence application. While licensing the outside service by filling out forms, such as types of outside services, regarding outside services, uploading outside official letters, uploading photos of outside service activities. 


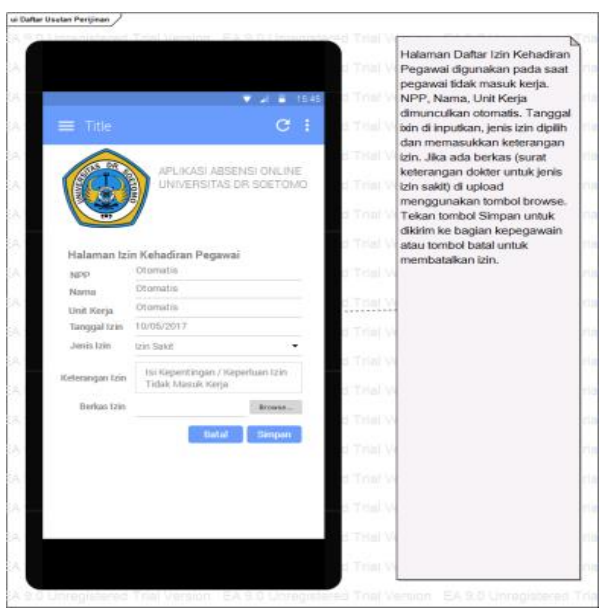

Fig. 4. GUI for Employee Attendance Licensing

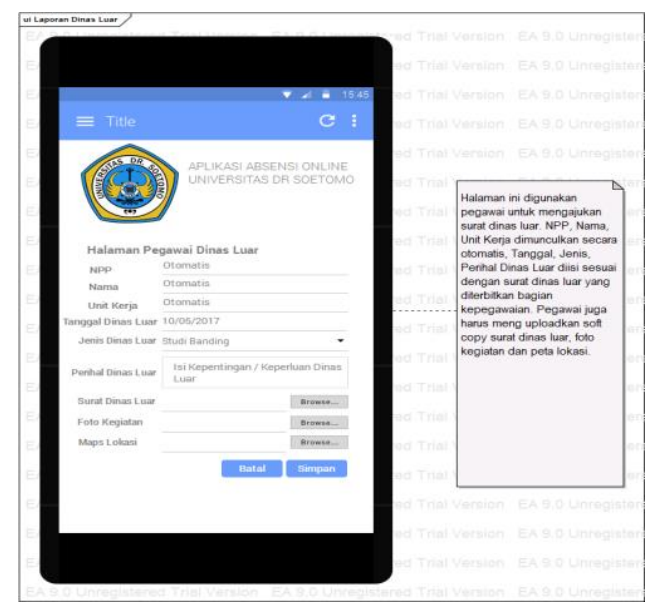

Fig. 5. GUI for Off-Service Offices

\subsection{Designing Use Case Diagrams for Online Presence Application}

\subsubsection{Use Case Diagram Download the Online Presence Application}

In the method used UML - Iconix Process, the second step is the creation of a Use case narrative. Use of Use Case Diagram is used to find out what functions are in a system and who has the right to use the application. In addition, there is also a Use case Narrative that makes it easy for users to understand the functions and user access rights of the application. Next is a picture Use Case Diagram Download Application Online presence.

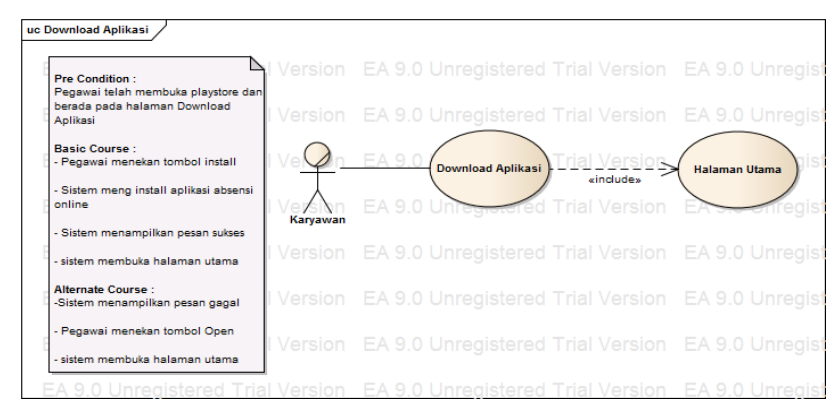

Fig. 6. Use Case Download Online Application

\subsubsection{Use Case Diagram for Employee Licenses at Online Presence Application}

Next is a picture of Use Case Employee Attendance Licensing Chart Online Addressing. Employees who want to do a permit must apply for permission then the staff verifies the permits for employees by attaching an application or permit. 


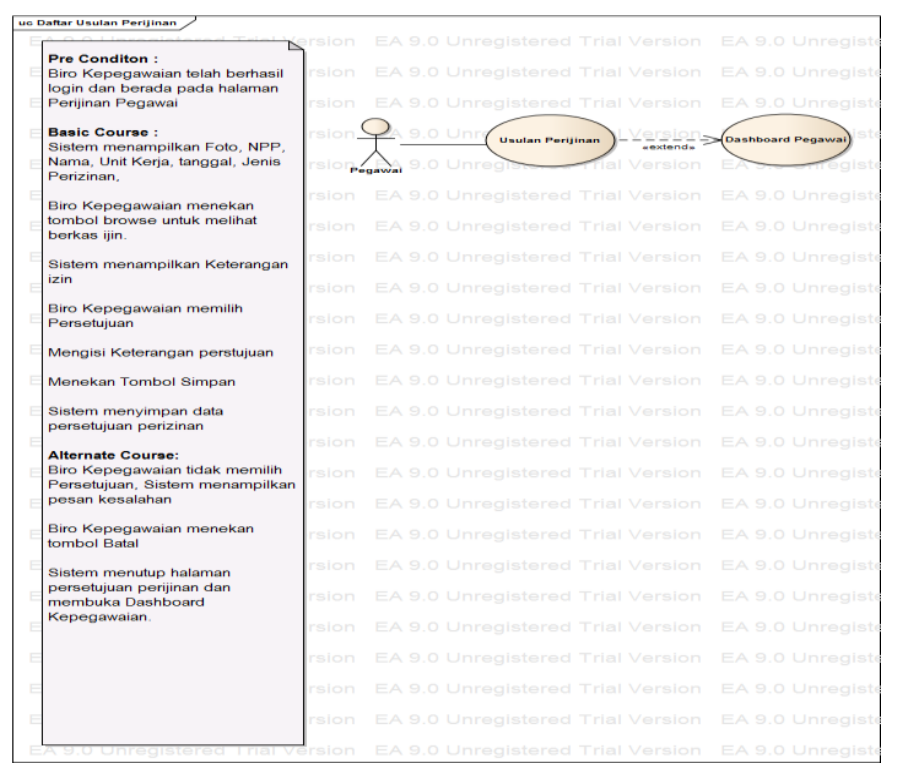

Fig. 7. Use Case Employee Attendance Licensing Diagram

a. Use Case Diagram of Outside Employee Service Reports on Online Presence Application

Use Case Diagram of Outside Employee Service Reports At Online presence, employees must upload assignments for external services and staff conduct verification, then on duty locations employees must upload activities during activities in carrying out their duties.

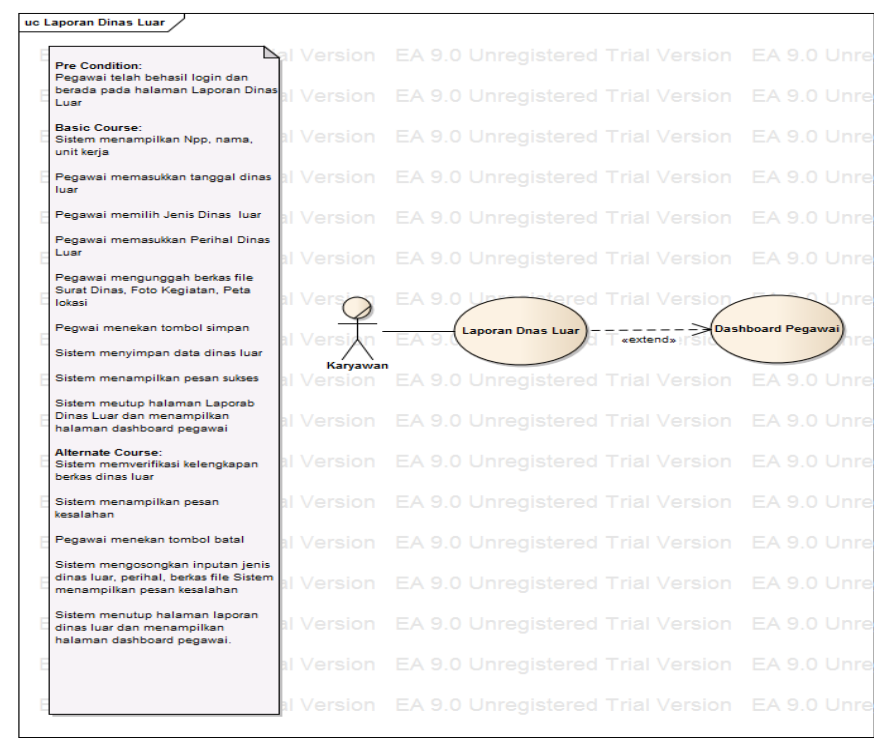

Fig. 8. Use Case Diagram for Outside Employee Service Reports 


\subsection{Robustness Diagram for Online Presence Application}

\subsubsection{Robustness Download Online Presence Application}

The third step is the making of the Robustness Diagram. Use of Robustness Diagram is to help bridge the existence of empty space from the actual design analysis of the coding implementation. Analyze the text use case and identify the initial assumption of the object for each use case. This Robustness diagram is classified into boundary objects, entity objects, and controllers (which usually function as verbs or activities). In addition, there is also a Use case Narrative that makes it easy for users to understand the functions and user access rights of the application. The following is a Robustness Diagram Download Online Presence Application

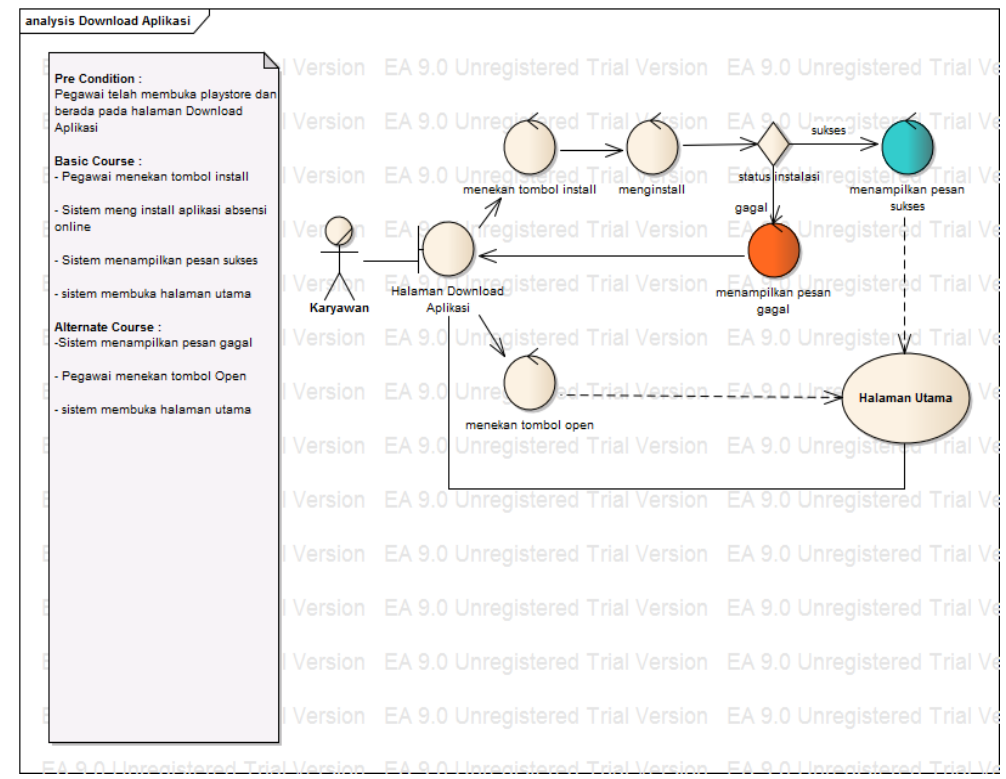

Fig. 9. Robustness Download the Online Application

\subsubsection{Robustness Diagram for Employee Licenses in Online Presence Application.}

The staffing office can look at the employee dashboard who has asked permission. The following is a picture of the Robustness Diagram for Licensing of Employee Presence on Online Presence Applications. 


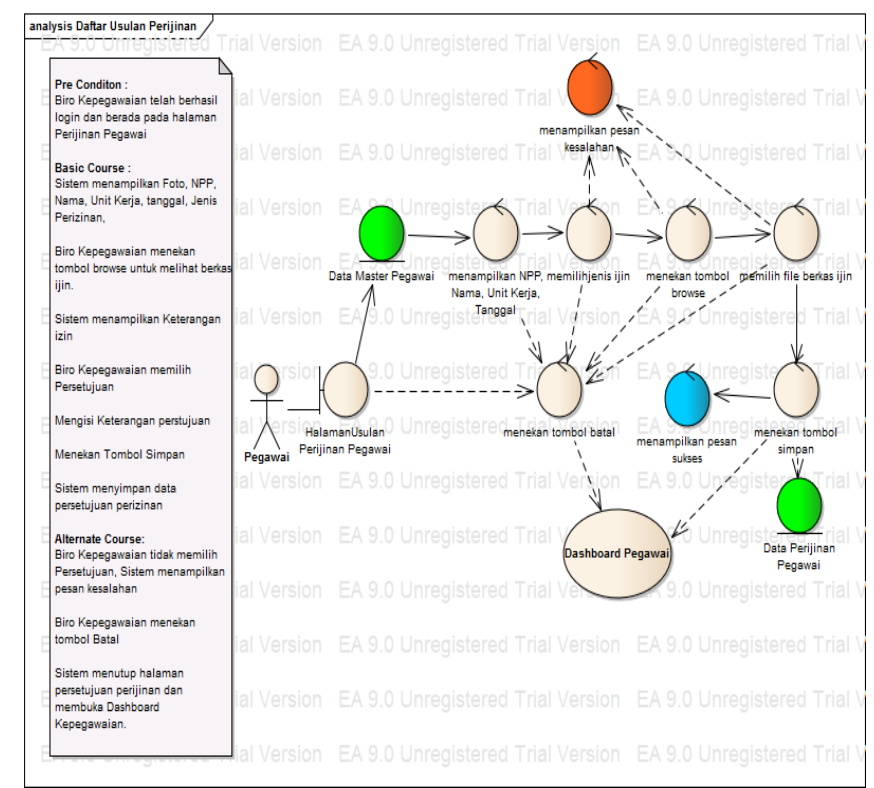

Fig. 10. Robustness Diagram of Employee Attendance Licensing

\subsubsection{Robustness Diagram for Licensing Off-Service Office}

The Robustness diagram of the licensing of external services is almost the same as the permit for sickness/leave, the difference is the upload of activities carried out during the outside service. The following is a Robustness Image Diagram of Off-Staff Service Reports on Online Presence Applications

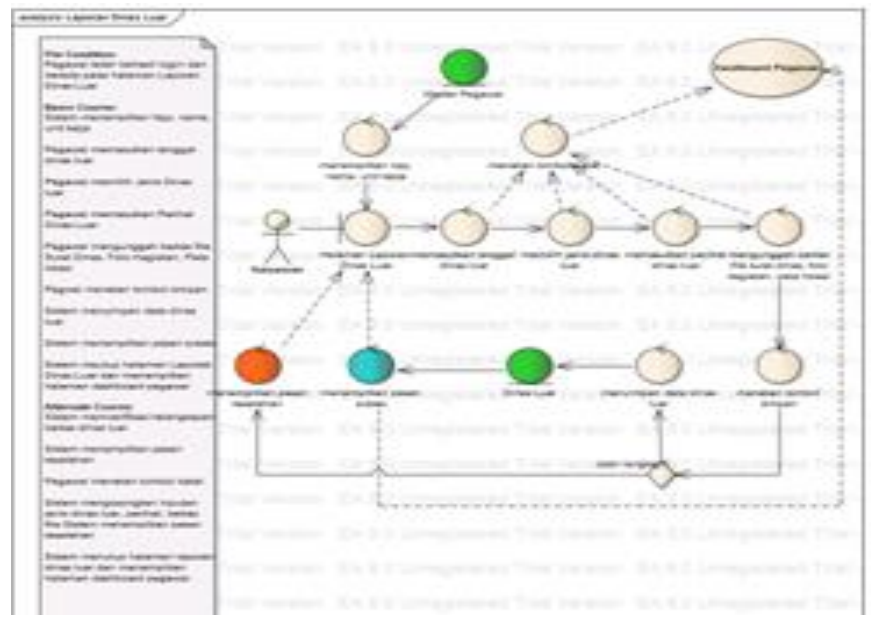

Fig. 11. Robustness Diagram of Off-Service Official Reports 


\subsection{Sequence Diagram for Online Presence Applications}

\subsubsection{Sequence Diagram Download Online Presence Application}

The fourth step is making Sequence Diagrams. The use of Sequence Diagrams is used to describe a scenario or series of steps carried out in response to an event to produce a specific output. In addition, Sequence diagrams are interactions between objects in and around the system (including users, displays, etc.) in the form of messages that are described against time. Sequence diagrams consist of vertical dimensions (time) and horizontal dimensions (related objects). There is a Use case Narrative that makes it easy for users to understand the functions and user access rights of the application. The following is a Robustness Diagram Download Online Presence Application

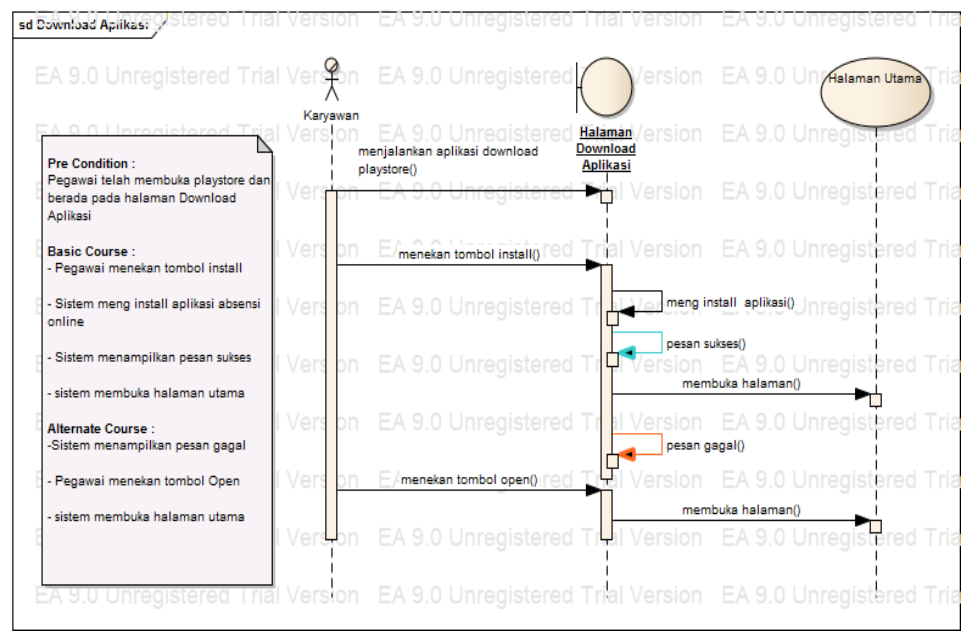

Fig. 12. Sequence diagram Download Online Application

\subsubsection{Sequence Diagram for Employee Attendance Licensing}

In the UML Iconix Process method, the fourth step is making Sequence Diagrams. Use of Sequence Diagrams is used to describe a scenario or series of steps that are carried out in response to an event to produce a specific output, besides Sequence diagrams are interactions between objects inside and around the system (including users, displays, etc.) in the form of a message that is described against time. Sequence diagrams consist of vertical dimensions (time) and horizontal dimensions (related objects). There is a Use case Narrative that makes it easy for users to understand the functions and user access rights of the application. The following is the Robustness picture of Employee Attendance Licensing Diagram in Figure 13. And Robustness of the Outer Service Diagram in Figure 14. 


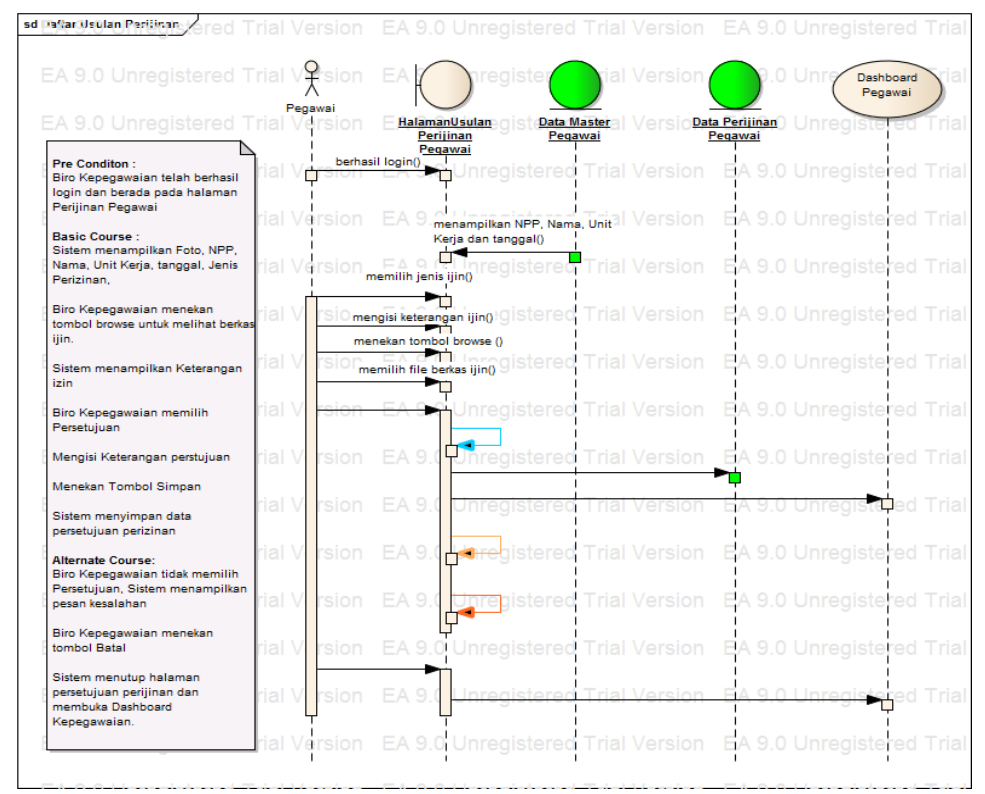

Fig. 13. Robustness Diagram of Employee Attendance Licensing

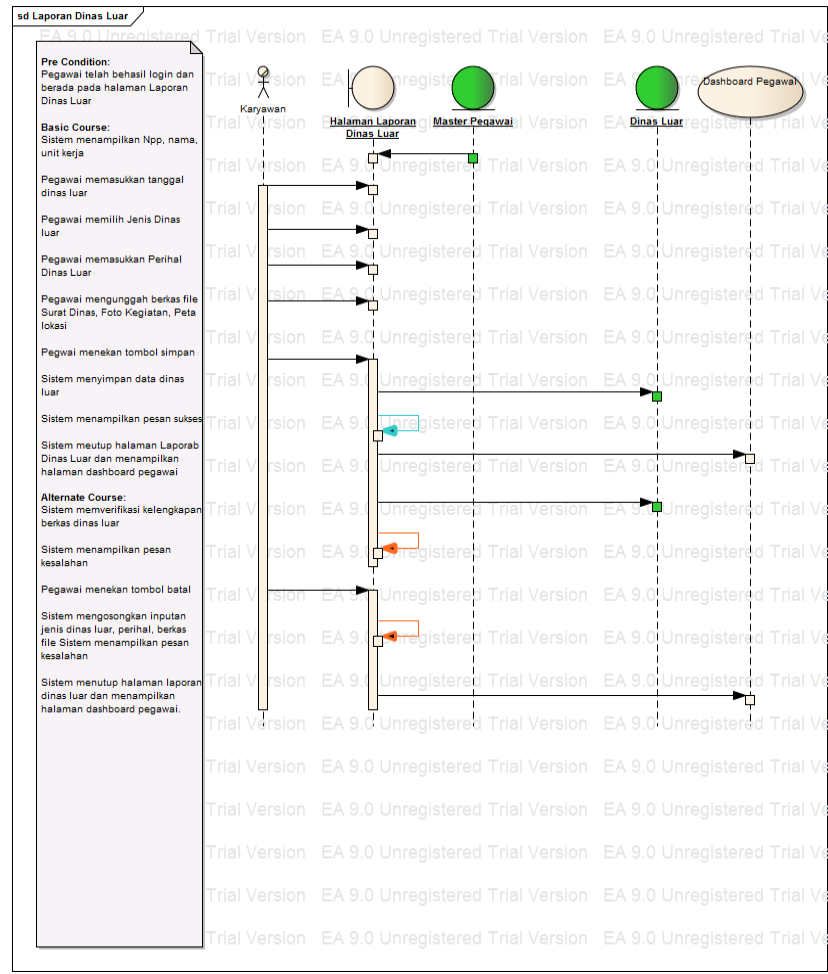

Fig. 14. Sequence Diagram of Off-Service Official Reports 


\section{Conclusion}

Software Requirements Specification (SRS) is very helpful for programmers in developing an online presence-based android application system so that the application is made according to user needs. With the SRS, it can reduce the time and cost of developing the application.

\section{Reference}

[1] K. R. Pireva and J. Siqeca, RFID : Management System for students 'attendance, vol. 46, no. 8. IFAC, 2013.

[2] J. Chi, B. Quadir, N. Chen, and Q. Miao, "Internet and Higher Education Effects of online presence on learning performance in a blog-based online course," Internet High. Educ., vol. 30, pp. 11-20, 2016.

[3] A. Andisa et al., "PENGARUH PENERAPAN SISTEM ABSENSI ONLINE DAN ELOGBOOK TERHADAP DISIPLIN KERJA PEGAWAI DI BADAN KEPEGAWAIAN DAERAH PROVINSI KALIMANTAN TIMUR,” vol. 5, pp. 5689$5702,2017$.

[4] S. Mamoudou, "Impact of Information Technology in Human Resources," vol. 4, no. 1, pp. 33-41, 2014.

[5] S. E. E. Profile, "System requirements analysis with ICONIX process case study : group project peer-assessment tool," no. February, 2019.

[6] "pedoman penataan tatalaksana," 2011.

[7] R. Nur, I. Sari, H. S. Hadijah, J. Setiabudi, N. Bandung, and J. B. Indonesia, "Peningkatan kinerja pegawai melalui kepuasan kerja dan disiplin kerja ( Reach employee performance by job performance and work discipline )," vol. 1, no. 1, pp. 204214, 2016

[8] M. Elhazzam, "The Effect of ICT on Human Resources Management Practices Case of Number of Organizations in Southwest Algeria ( Bechar City ),” no. 3, pp. 3-6, 2015.

[9] D. Karanja, "Integration of ICT in Human Resource Management: Case of Kenyan Higher Education," vol. 6, no. 2, pp. 34-41, 2016.

[10] D. Karanja, A. Kiplang, and M. Ndirangu, "Influence of Integration of ICT on Human Resource Management in Kenyan Public Universities," vol. 3, no. 6, pp. 73-78, 2018.

[11] D. Rosenberg and M. Stephens, Use Case Driven Object Modeling with UML Theory and Practice. .

[12] S. Geagea, "Software Requirements Specification Amazing Lunch Indicator," 1933. 